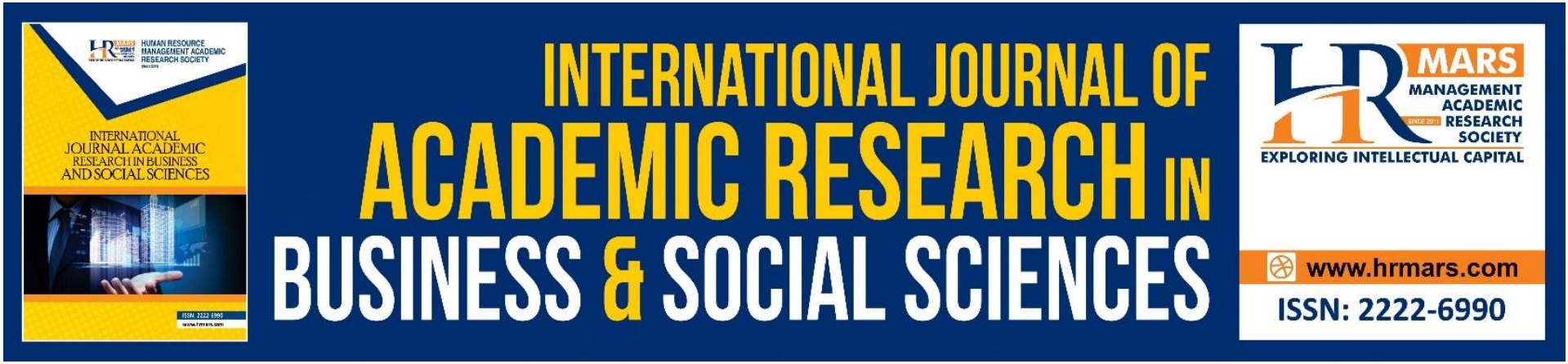

\title{
Task Performance and Information Technology Usage: The Mediating Role of the IT Department
}

\section{Malek Al-edenat, Ahmad Alzaghmim}

To Link this Article: http://dx.doi.org/10.6007/IJARBSS/v12-i1/11961

DOI:10.6007/IJARBSS/v12-i1/11961

Received: 20 November 2021, Revised: 22 December 2021, Accepted: 06 January 2022

Published Online: 28 January 2022

In-Text Citation: (Al-edenat \& Alzaghmim, 2022)

To Cite this Article: Al-edenat, M., \& Alzaghmim, A. (2022). Task Performance and Information Technology Usage: The Mediating Role of the IT Department. International Journal of Academic Research in Business and Social Sciences, 12(1), 1323-1339.

Copyright: (c) 2022 The Author(s)

Published by Human Resource Management Academic Research Society (www.hrmars.com)

This article is published under the Creative Commons Attribution (CC BY 4.0) license. Anyone may reproduce, distribute, translate and create derivative works of this article (for both commercial and non0-commercial purposes), subject to full attribution to the original publication and authors. The full terms of this license may be seen at: http://creativecommons.org/licences/by/4.0/legalcode

Vol. 12, No. 1, 2022, Pg. $1323-1339$

http://hrmars.com/index.php/pages/detail/IJARBSS

Full Terms \& Conditions of access and use can be found at http://hrmars.com/index.php/pages/detail/publication-ethics 


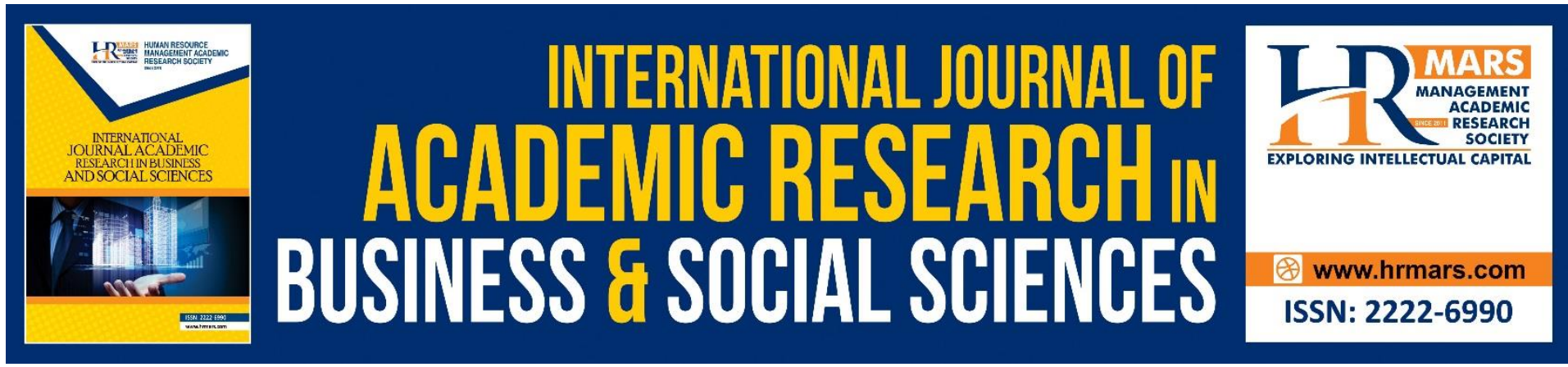

\title{
Task Performance and Information Technology Usage: The Mediating Role of the IT Department
}

\author{
Dr Malek Al-edenat Corresponding Author \\ Business Department, Tafila Technical University, Jordan \\ Email:malek@ttu.edu.jo,mohaabmalek@yahoo.com \\ Mr Ahmad Alzaghmim \\ Presidency Office, Tafila Technical University, Jordan \\ Email: zaghmim@gmail.com
}

\begin{abstract}
This study aims at investigating the impact of Information Technology (IT) usage on task performance (TP) in Jordanian public universities (JPUs). In addition, the study examines the mediation role of the Information Technology department (ITD) in this relationship. A questionnaire survey was sent online to the employees in public universities, and the number of respondents was 997 employees. The data were analyzed using SPSS and AMOS23. The study's findings revealed that information technology usage plays a significant role in improving employees' task performance. The results showed that information technology usage positively and directly affects task performance. The results also showed that the information technology department plays a partial mediator role in the relationship between information technology usage and the workers' task performance. The current study suggests that an essential need to switch to computerized management information systems to a gradual switch to electronic management is needed to enhance task performance. Adopting internal electronic correspondence rather than paper contributes significantly to minimizing administrative financial expenses and speed task performance in order to completing work and developing E-HRM in universities. They have a crucial role in switching to electronic management and digitalization. Limitations and directions for future researches are, likewise, discussed.
\end{abstract}

Keywords: Information Technology (IT), Task Performance (TP), Information Technology Department (ITD), Jordanian Public Universities (JPUs).

\section{Introduction}

Generally, there is a little understanding of the changing patterns and effects of Information Technology (IT) use. In addition, most of the previous research has studied the use of various technologies. Still, most researchers tend to search IT applications as a black box instead of specific feature sets (Jasperson, Carter \& Zmud, 2005). Simultaneously, most of the researches conducted in organizations indicated that IT applications were still not taking advantage of these functional capabilities (Benlian, 2015). In such manner, Jasperson, 
Carter \& Zmud (2005, p.525) concluded that "users employ quite narrow feature breadths, operate at low levels of feature use, and rarely initiate technology-or task-related extensions of the available features", which implies that a substantial potential emerging from IT use still undiscovered. More experienced users typically have a richer comprehension of the IT characteristics' affordances; thus, they are well prepared to benefit from their experience when executing tasks (Taylor \& Todd, 1995).

IT has become a catalyst for organizations looking for excellence in their products and Efficiency and effectiveness in their performance. Consequently, organizations are accelerating IT's use in finding new and innovative opportunities such as raising the level of job performance, improving administrative decisions, simplifying procedures, and optimizing the use of available materials. Further, training employees in using IT ensures work with accuracy, speed, and mastery and reaches high-performance standards for employees (Marler et al., 2006). The most recent conception is that the impact of reputable resources may set out through some other element which includes, resource complementary and organizational capabilities. Resource complementary explains that the combination of complementary resources can be driving a Cooperative that can reflect better performance (Karimi et al., 2007).

Whereas, task performance has always been the central point of organization operations, and management literature discussions comprise competitiveness, effectiveness, efficiency (Jalagat \& AL-habsi, 2017). According to Motowildo, Borman \& Schmit (1997), organizations set or expanded their objectives to achieve the best organizational task performance and direct their operational processes to align with these corporate objectives. However, significant changes in the higher education environment have forced orgnizations to change the way of managing their daily activities due to rapid changes in the light of the internet, globalization, and the diversity of the workforce (Uwizeyemungu \& Raymond, 2010). Accordingly, the year 1990 marks the employment of electronic human resource management that has developed the IT usage model and being continuously used since 2000 . Lately, its usable include virtual learning environment and many activities that realize the significance of electronic human resource management as appeared in universities' rising use daily (Hampel \& Pleines, 2013).

Hence, the current study will be conducted on the chosen organizations, JPUs, 10 public universities operating in Jordan and located in different cities all around Jordan. As IT has been implemented in classrooms and the employee's task performance in several departments. The implementation includes, for examples the Financial Department, Admission and Registration, the Supplies Department, the Deanship of Student Affairs, the Student Services Department, the Diwan and Electronic Archiving section, the Human Resources Department. However, employees still not recognize whether the IT has already been completely applied or not, whereas traditional work still using (paperwork) in performing their duties or using modern devices in addition to paperwork. In turn, adds to employees new burdens in the performance of their tasks.

Consequently, this guides into essential question that necessarily to be addressed, why still use traditional methods for completing tasks while there are modern methods? Employees still perceived that the IT is yet untapped and some functions required to be taken due consideration, for instance, marge university systems into Enterprise Resource Systems to smooth administrative processes and consolidation university data. So, this study aims at investigating the impact of IT usage on task performance at JPUs. Does the IT department play as a mediation in the relationship between IT usage and task performance? 


\section{Theoretical Framework}

\section{Information Technolgy, Information Technology Department and Task Performance}

According to Koenig (2013), IT has changed many modern management concepts. So, IT is not an end in itself, but rather is a method used by organizations to support management in its operations and activities and meet their information needs provided to users on time. Therefore IT has a fundamental and direct impact on the workflow, the size of the workforce, investment patterns, and trends when IT is a capital investment in itself (Ting, Carin, Dzau, \& Wong, 2020). Whereas, knowledge management, however, close to assure the static asset of knowledge acquired by an organization and the feature of that knowledge, rather than the active method through which knowledge is bullied by organizations (Vera \& Crossan, 2003). Turban et al (2006) argued that IT's most critical advantages are to increase the organization's ability to improve quality and provide better services to customers in a manner consistent with their expectations and contribute to increasing their satisfaction with these services. In this context, Gupta \& Berkley (1994) believed that IT contributes to simplifying and facilitating procedures for obtaining services provided by service organizations, giving time for customers who wish to receive these services and improving the level and quality of services offered.

Morover, Brynjolfsson \& Hitt (2000) emphasized that IT contributes to implementing and completing other organizational investments, such as the re-engineering of activities or operations. These investments increase productivity by reducing costs and increasing the quality of outputs, whether in new products or improving aspects of intangible forms in existing products. Consistently, O'Leary (2000) confirmed that IT has contributed to the emergence of new products and services that are more quality and less expensive and have also contributed to establishing new relationships between customers. Simirarly, FragaLamas et al (2017) emphasized that information and communication technologies and dependence on computer systems have contributed to improving customer values and increasing their satisfaction with the level of services provided. IT's impact has not been limited to improving the quality of services provided to clients over private organizations and extended to public organizations. Further, Wang et al (2020), revealed that ICT usage influences employees by forming three crucial work design facets: job demands, job autonomy, and relational aspects. In addition, they classify two groups of elements that act as a moderation effect of ICT usage on work design: elements of fit user-technology and elements of fit social-technology fit. This multi-disciplinary evaluation emphasizes work design as a fundamental explanatory tool for discovering how individual IT usage affects employees' effectiveness and well-being. Consist with that, it has been found that IT is reducing the procedures and time needed to deliver the product to the customer (Eljhani \& Ameen, 2020).

Based on the above discussion, the authors proposed that:

H1: Information Technology (IT) holds a direct and positive impact on Task Performance (TP)

H1a: Information Technology (IT) holds a direct and positive impact on quality of performance H1b: Information Technology (IT) holds a direct and positive impact on Speed of performance H1c: Information Technology (IT) holds a direct and positive impact on the Efficiency of performance

H1d: Information Technology (IT) holds a direct and positive impact on Simplification of work H2: Information Technology Department (ITD) holds a direct and positive impact on Task Performance (TP) 


\section{Informationa Technology Usage and Information Technology Department}

Commonly, organizations ought to repeatedly obtain information regarding the evolving IT from a variety of external sources, comprehend their features and operationality, as well as earn the latest knowledge. The IT department can probablly augment the efficiency of the scanning information process through finishing these actions for the organization. Moreover, IT department is exclusively situated to obtain information about evolving IT since classifying technological tendencies is a significant factor of an IT employee's work (Ang \& Slaughter, 2000; Brown \& Eisenhardt, 1997; Kiesler \& Sproull, 1982). Therefore, IT specialists are continuously in touch with the majority of the organizatins' departments and improve business knowledge, operations, services and products of the organization (Gordon \& Tarafdar, 2010).

The IT department reinforced the organizations' departments through offering them with teamwork infrastructures, and computing, communication system and skills, and applications of project and knowledge management, correspondingly, appling and sustaining organization's systems to boost the manufacturing, logistics, sales, and service after-sales (Tarafdar \& Tanriverdi, 2018). As a result, IT departments are frequently overloaded with traditional tasks and responsibilities such as structuring and operating organization's IT systems that maintain additional designed and normalized business processes in human resource, finance, logistics, sales and other roles (Ross, Weill, \& Robertson, 2006). Additionally, the IT department may likewise, distribute the knowledge regarding the emerging IT to the whole organization in order to increase consciousness of the business units about it. Whereas, it can do this through running discussions to deliberate and communicate their particular knowledge with operational directors within organizations' departments and top management (Agarwal \& Sambamurthy, 2002; Pawlowski \& Robey, 2004; Swanson \& Ramiller, 2004).

Based on the discussion above we argue that:

H3: Increasing Information Technology usage (IT) will increase the role of Information Technology Department (ITDR) within Jordanian Public Universities (JPUs).

\section{The Role of Information Technology Department}

Two different perspectives have been employed in this study: first, the resource-based view (RBV) (Hart, 1995; Wernerfelt, 1984; Wu et al., 2006). Second, institutional theory (Hanson, 2001; Tina Dacin, Goodstein, \& Richard Scott, 2002; ) to test the relationship between institutional factors and resources of the firm and task performance under the mediating effect of ITD. On the one hand, RBV shows how an organization can gain a competitive advantage by creating strategic resources and capabilities. Gupta \& George (2016) stated that tangible resources (core resources, technology, and data) and human skills (technical skills and managerial skills) help to build IT and task capabilities. Further, a resource-based perspective is a useful technique for predicting performance (Bromiley \& Rau, 2016). The (RBV) introduces one serious clarification: if organizations are viewed as a diverse package of resources, given organizations may obtain an advantage depending on their unique access to scarce resources. Specifically, resources have been worthy, scarce, and difficult to imitate, and the organizations have to be organized to gain the advantage of them (Wernerfelt, 1984). Moreover, supporters of the resource-based view mostly suppose that there is a perfect link between having strategic resources and an organization's task performance (Almarri \& Gardiner, 2014; Terziovski, 2010). 
On the other hand, Institutional Theory has emerged to distinction as a widespread and influential clarification of both individual and organizational activity. It is an energetic theory that has been produced and differed with a several of other tactics. While its domain has indeed been extended, institutional theory has frequently been panned since it is mainly utilized to clarify the stability and consistency of phenomena. The styles offer patterns for the scheme of organizational structures: the jobs, rules, agendas, and actions of new organizations (Meyer \& Rowan, 1977). These styles employ their influence, not through their impact on organizational members' task actions, instead, job actions are predominantly separated from regulation schemes or the accounts describing them, yet on investors and external public. As aresult, the adoption of these schemes by the organization gains community authenticity (Scott, 2005).

Based on the above discussion and arguments, we propose that:

H4: Information Technology Department (ITD) mediates the relationship between Information Technology (IT) and Task Performance (TP)

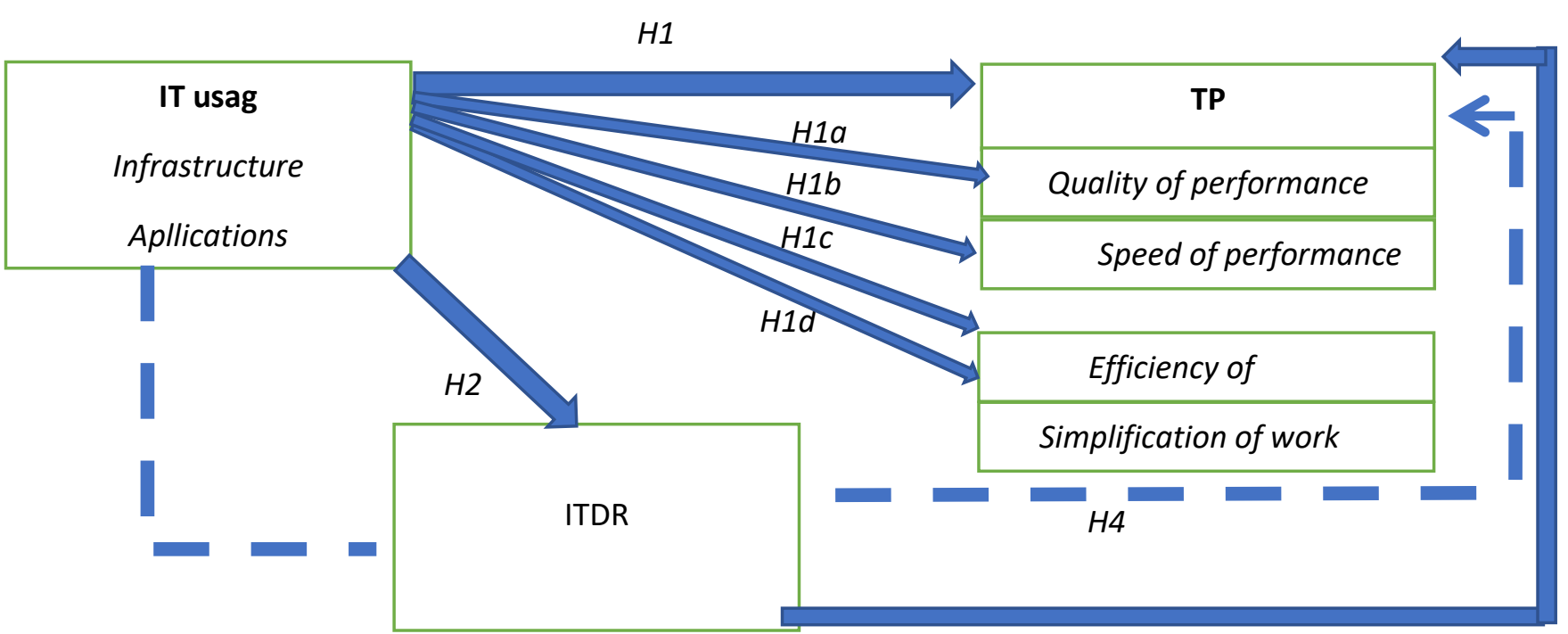

Figure 1 Proposed model

$H 3$

\section{Data, Methods and analysis \\ Population and sampling}

The current study mainly investigates the impact of IT on TP as well as investigates the mediation role of ITD in this relationship. A questionnaire survey was the primary tool in order to deal with the analytical aspects of the research. The questionnaires were distributed to highlight IT usage's impact on task performance and examine the IT Department's mediating role in this relationship. The targeted population is the higher education sector in Jordan. The questionnaire was sent to the participants via email. The number of the distributed questionnaires was 2000 form different departments in JPUs, only 997 questionnaires were returned and valid for analysis. This gives approximately a 50 per cent response rate.

\section{Measurements}

A comprehensive literature review was conducted to develop the questionnaire appropriately to test the study's proposed model. A process of translation and back translation, by experts, to Arabic also took place since the original measurements were in the English language. Moreover, verifying the content validity, the questionnaire was purified via 
precise pre-testing. In the process of pre-testing, we paid more attention to the instrument clarity, question-wording and validity. Based on this process, six elements were excluded from the instrument. A five-point Likert scale was used to assess all measures, ranging from "strongly disagree" to "strongly agree".

IT usage is measured with two factors, (IT infrastructure, IT application). Whereas, eleven items adapted from Abouelmagd (2016) were used. An example of the items for IT Infrastructure factor "IT provides the employees with the latest technology and the university's information applications is reliable". An example of the items for IT application factor "The information provided by the IT Applications is reliable". Moreover, task performance was measured using a items adapted from the study of (Koopmans et al., 2011; Faraj, 2012; Jabbouri et al., 2016).

\section{Analysis and Results}

To ensure the discriminant validity, two exploratory factor analyses were performed. First, the items regarding, TP and ITD were yielded to a principal components' analysis. Table 1 shows the factors loading: Eigenvalues greater than 1, with 8.67 and 13.23 per cent of the variance, respectively. Each item for each construct was "loaded" on its identifiable construct, with main loadings above .45 with cross-loadings less than 0.30 . Second, regarding the IT variable, the items were yielded to principal components analyses as well. As shown in Table 2 , the factor that showed applicably embodied the IT items, the main loadings surpassed 0.69 , whereas cross-loadings were less than 0.29 . The factors had eigenvalues greater than 1 , with 76.46 per cent of the variance (Hair et al., 2010).

Table 1 Factor Loading

\begin{tabular}{|l|l|l|l|}
\hline Information Technology Usage (IT) & \multicolumn{2}{l|}{ Factors' loading } & 0.05 \\
\hline $\begin{array}{l}\text { IT provides university employees with the } \\
\text { latest technology in computers }\end{array}$ & $\mathbf{0 . 6 5}$ & 0.04 & 0.07 \\
\hline $\begin{array}{l}\text { The university computer Networks are } \\
\text { always available and reliable }\end{array}$ & $\mathbf{0 . 7 2}$ & 0.06 & 0.10 \\
\hline $\begin{array}{l}\text { The voice communication with all university } \\
\text { sites are always available and reliable }\end{array}$ & $\mathbf{0 . 7 1}$ & 0.12 & 0.02 \\
\hline $\begin{array}{l}\text { The Email Service is always available and } \\
\text { reliable }\end{array}$ & $\mathbf{0 . 6 8}$ & 0.03 & 0.08 \\
\hline The data storage capacity is sufficient & $\mathbf{0 . 8 0}$ & 0.07 & .020 \\
\hline $\begin{array}{l}\text { The information provided by the IT } \\
\text { Applications of the university is reliable }\end{array}$ & $\mathbf{0 . 6 6}$ & 0.21 & 0.11 \\
\hline $\begin{array}{l}\text { The information provided by the IT } \\
\text { Applications of the university is accurate }\end{array}$ & $\mathbf{0 . 7 1}$ & 0.10 & 0.06 \\
\hline $\begin{array}{l}\text { IT Applications of the university provide } \\
\text { users with the complete information that is } \\
\text { needed }\end{array}$ & $\mathbf{0 . 8 2}$ & 0.07 & -0.01 \\
\hline $\begin{array}{l}\text { Employees have sufficient understanding of } \\
\text { IT Applications }\end{array}$ & $\mathbf{0 . 9 0}$ & -0.02 & -0.05 \\
\hline $\begin{array}{l}\text { IT Applications of the university facilitate } \\
\text { user-friendly interface }\end{array}$ & $\mathbf{0 . 8 4}$ & -0.06 & 0.07 \\
\hline $\begin{array}{l}\text { IT Applications of the university are aligned } \\
\text { with company processes and objective }\end{array}$ & $\mathbf{0 . 8 6}$ & 0.11 \\
\hline
\end{tabular}




\begin{tabular}{|c|c|c|c|}
\hline \multicolumn{4}{|l|}{ Information technology Department (ITD) } \\
\hline $\begin{array}{l}\text { IT Division has deployed sufficient } \\
\text { Personnel to provide IT services }\end{array}$ & -0.12 & 0.82 & -0.22 \\
\hline $\begin{array}{l}\text { IT Personnel solve the problem in the first } \\
\text { instance }\end{array}$ & -0.17 & 0.84 & -0.15 \\
\hline $\begin{array}{l}\text { IT Personnel keep users well informed about } \\
\text { the progress of users' complaints }\end{array}$ & -0.20 & 0.78 & -0.22 \\
\hline $\begin{array}{l}\text { IT Personnel handle users' } \\
\text { complaints/queries seriously }\end{array}$ & 0.01 & 0.77 & 0.02 \\
\hline $\begin{array}{l}\text { IT Personnel inform users exactly when } \\
\text { maintenances will be performed }\end{array}$ & -0.23 & 0.79 & -0.18 \\
\hline $\begin{array}{l}\text { IT Personnel are friendly and polite with } \\
\text { users }\end{array}$ & -0.13 & 0.74 & -0.15 \\
\hline $\begin{array}{l}\text { IT Personnel are knowledgeable enough to } \\
\text { perform their job }\end{array}$ & -0.27 & 0.76 & -0.25 \\
\hline $\begin{array}{l}\text { IT Personnel are continuously in touch with } \\
\text { the users }\end{array}$ & 0.02 & 0.77 & 0.03 \\
\hline \multicolumn{4}{|l|}{ Task Performance (TP) } \\
\hline \multicolumn{4}{|l|}{ Quality of wrok } \\
\hline $\begin{array}{l}\text { The quality of my work has improved over } \\
\text { the past three months }\end{array}$ & 0.01 & 0.02 & 0.69 \\
\hline $\begin{array}{l}\text { I was able to perform my work well with } \\
\text { minimal time and effort. }\end{array}$ & 0.03 & 0.03 & 0.68 \\
\hline $\begin{array}{l}\text { I'm satisfied regarding the evaluation of my } \\
\text { performance in work in the past three } \\
\text { months }\end{array}$ & -0.13 & -0.16 & 0.76 \\
\hline $\begin{array}{l}\text { The quality of my work has been below what } \\
\text { it should have been in the past three months }\end{array}$ & -0.12 & -0.18 & 0.77 \\
\hline \multicolumn{4}{|l|}{ Speed of Performance } \\
\hline $\begin{array}{l}\text { I managed to plan my work so that it was } \\
\text { done on time. }\end{array}$ & -0.30 & -0.32 & 0.84 \\
\hline $\begin{array}{l}\text { The flow of information in the university are } \\
\text { characterized, being speedy and safe to } \\
\text { ensure the speed flow of accurate } \\
\text { information between departments and } \\
\text { decision-makers }\end{array}$ & -0.18 & -0.20 & 0.83 \\
\hline $\begin{array}{l}\text { The speed of communication and transfer } \\
\text { information has been increased in my } \\
\text { workplace in the last three months. }\end{array}$ & -0.19 & -0.25 & 0.90 \\
\hline $\begin{array}{l}\text { I'm able to complete tasks and send circulars } \\
\text { and decisions too quickly to the concerned } \\
\text { authorities. }\end{array}$ & -0.22 & -0.24 & 0.91 \\
\hline \multicolumn{4}{|l|}{ Efficiency of Performance } \\
\hline I work towards the end result of my work. & -0.30 & -0.31 & 0.89 \\
\hline $\begin{array}{l}\text { I kept in mind the results that I had to } \\
\text { achieve in my work. }\end{array}$ & -0.22 & -0.18 & 0.87 \\
\hline
\end{tabular}




\begin{tabular}{|l|l|l|l|}
\hline $\begin{array}{l}\text { It took me longer to complete my work tasks } \\
\text { than intended. }\end{array}$ & -0.12 & -0.19 & $\mathbf{0 7 8}$ \\
\hline $\begin{array}{l}\text { In general, I think technology has improved } \\
\text { the accuracy of records that are kept in the } \\
\text { university }\end{array}$ & 0.02 & 0.02 & $\mathbf{0 . 6 6}$ \\
\hline Simplification of Work & \multicolumn{2}{|l|}{} \\
\hline $\begin{array}{l}\text { Compared to last year, I can judge the } \\
\text { quality of my work for the past three months } \\
\text { that it has increased }\end{array}$ & -0.22 & -0.25 & $\mathbf{0 . 7 7}$ \\
\hline $\begin{array}{l}\text { The quantity of my work less than it should } \\
\text { have been in the past three months? }\end{array}$ & -0.24 & -0.22 & $\mathbf{0 . 8 7}$ \\
\hline I had trouble setting priorities in my work. & -0.18 & -0.17 & $\mathbf{0 . 8 3}$ \\
\hline $\begin{array}{l}\text { I was able to coordinate my work and to } \\
\text { separate the main issues from side issues at } \\
\text { work. }\end{array}$ & 0.02 & 0.01 & $\mathbf{0 . 8 1}$ \\
\hline
\end{tabular}

Although previous studies have shown a high-reliability level, the researchers have retested reliability for all factors, representing in table 2.

\section{Simple Descriptive Statistics}

Table I represents simple statistical descriptive values, such as the means, standard deviations, and correlations of the study's variables (the independent and dependent variables).

Table 2 Simple Descriptive

\begin{tabular}{|l|l|l|l|l|l|}
\hline & $\boldsymbol{\mu}$ & SD & $\mathbf{1}$ & $\mathbf{2}$ & $\mathbf{3}$ \\
\hline IT & 3.66 & 0.63 & $(0.795)$ & & \\
\hline ITD & 3.73 & 0.54 & $0.543^{*}$ & $(0.818)$ & \\
\hline TP & 3.58 & 0.58 & $0.532^{*}$ & $0.547^{*}$ & $(0.755)$ \\
\hline
\end{tabular}

Note: Cronbach's $\alpha$ estimates are represented within parentheses along the diagonal. ${ }^{*} p>$ 0.001

\section{Structural Model}

Moving on, Amos23 is employed as well in this analysis. The proposed relationships among the variables of the current study are verified via utilizing SEM. Typically, SEM includes two stages: First, measuring the constructs' convergent validity through "measurement model". Second, assessing and testing casual relationships between constructs "structural model" (Hair et al., 2010). After that, the confirmatory factor analysis (CFA) was conducted to evaluate the measurement model. Prior to employing SEM, the data's sanitizing and screening procedure took place through functioning exploratory factor analysis (EFA) (Hair et al., 2010). Table 3 presents the fit indices of the measurement model. 
INTERNATIONAL JOURNAL OF ACADEMIC RESEARCH IN BUSINESS AND SOCIAL SCIENCES Vol. 12, No. 1, 2022, E-ISSN: 2222-6990 @ 2022 HRMARS

Table 3 The fit of indices of the Measurement Model

\begin{tabular}{|l|l|l|l|}
\hline Indices & IT & ITD & TP \\
\hline$\chi^{2}$ & 210.821 & 213.467 & 78.146 \\
\hline $\mathbf{d f}$ & 105 & 110 & 52 \\
\hline $\boldsymbol{\chi}^{\mathbf{2}} / \mathbf{d f}$ & 2.007 & 1.941 & 1.503 \\
\hline RMSEA & 0.032 & 0.038 & 0.041 \\
\hline CFI & 0.963 & 0.976 & 0.0953 \\
\hline $\mathbf{N F I}$ & 0.962 & 0.958 & 0.978 \\
\hline TLI & 0.974 & 0.972 & 0.976 \\
\hline GFI & 0.973 & 0.978 & 0.976 \\
\hline AGFI & 0.977 & 0.975 & 0.979 \\
\hline
\end{tabular}

H1a-d hypothesized the direct and positive impact of IT usage on TP in TUU. H2 hypothesized (ITDR) holds a direct and positive impact on TP in JPUs. Finally, H3 hypothesized that (ITDR) mediates the relationship between IT usage and TP in JPUs.

In this phase of the analysis, the paths analysis was the choice to examine the direct impact of IT usage on TP, on the one hand. On the other hand, examine the indirect effect of ITDR a mediator in the former relationship. This mediation impact will be confirmed by examining the significance or non-significance of different paths (MacKinnon, Cheong, \& Pirlott, 2012). Therefore, the results obtained via AMOS23 for the direct impact, the researchers observed that IT usage directly and positively impact the TP within JPUs with a total impact of $=0.387, C R=9.95$, and standard error (SE) 0.038. Moreover, the sub-impact on the four dimensions of TP as, for IT on the quality of performance estimate $=0.323, \mathrm{CR}=$ 7.690 , and $S E=0.042$. TP on the speed of performance with estimate $=0.289, C R=5.558$, and $\mathrm{SE}=0.052$. TP on performance efficiency with estimate $=0.256, \mathrm{CR}=2.876$, and $\mathrm{SE}=0.089$. Finally, TP on simplification of work with estimate $=0.266, C R=3.595$, and SE $=0.074$.

Moreover, the results showed that ITDR directly and positively impacts TP in JPUs. Whereas the total impact of ITDR was $0.812, C R=8.286$, and SE $=0.098$, Table III shows the results of testing the hypotheses regarding the, on the one hand, the direct impact of IT usage on TP, on the other hand, the direct impact of ITDR on TP.

Table 4 Hypotheses testing results

\begin{tabular}{|c|c|c|c|c|c|c|c|}
\hline Construct & Code & Hypothesis & Direction & Estimate & SE & CR & Result \\
\hline $\begin{array}{l}\text { Information Technology } \\
\text { Usage }\end{array}$ & IT & \multirow[t]{2}{*}{$\mathrm{H} 1$} & \multirow[t]{2}{*}{$\mathrm{IT} \longrightarrow \mathrm{TP}$} & \multirow[t]{2}{*}{0.387} & \multirow[t]{2}{*}{0.038} & \multirow[t]{2}{*}{7.690} & \multirow[t]{2}{*}{ Supported } \\
\hline Task Performance & TP & & & & & & \\
\hline Quality of Performance & $\mathrm{TPQ}$ & $\mathrm{H} 1 \mathrm{a}$ & $\mathrm{IT} \longrightarrow \mathrm{TPQ}$ & 0.323 & 0.042 & 7.690 & Supported \\
\hline Speed of Performance & TPS & $\mathrm{H} 1 \mathrm{~b}$ & $\mathrm{IT} \rightarrow \mathrm{TPS}$ & 0.289 & 0.052 & 5.558 & Supported \\
\hline Efficiency of performance & TPE & $\mathrm{H} 1 \mathrm{c}$ & $\mathrm{IT} \longrightarrow \mathrm{TPE}$ & 0.256 & 0.089 & 2.876 & Supported \\
\hline Simplification of Work & TPSW & $\mathrm{H} 1 \mathrm{~d}$ & $\stackrel{I T}{\longrightarrow}$ TPSP & 0.266 & 0.074 & 3.595 & Supported \\
\hline $\begin{array}{l}\text { Information Technology } \\
\text { Department Role }\end{array}$ & ITDR & $\mathrm{H} 2$ & $\mathrm{ITDR} \longrightarrow \mathrm{TP}$ & 0.812 & 0.098 & 8.286 & Supported \\
\hline
\end{tabular}

Regarding the mediation impact of ITDR on TP, Preacher and Hayes (2004, p. 719) declared that "The indirect effect of the independent variable on the dependent variable through a mediator variable is likely to be assessed by the product of two paths. First, the path between the independent variable and the mediator variable. Second, the path between the mediator variable and the dependent variable". As a result, the mediation effect could be 
more directly addressed through a significance test related to these paths, than several separate significance tests that not directly include this path.

Consequently, Preacher \& Hayes (2004) recommended a more trustworthy tactic for examining mediation impact would be to require just occurrence of an impact to be mediated (this means, the relationship between the independent variable IT uasge and the dependent variable TP should not equal zero). Besides, the indirect impact to be statistically significant in the direction is expected to occur through the mediator ITDR. Based on these conditions, the Sobel's (1982) model is required, while, it is the case in the model of the present study. The mediation impact in the present study arises as the direct impact of the independent variable, IT usage, on the dependent variable, TP, is significant; yet, it is more significant with the existence of the mediator variable, ITDR (Hair et al., 2010; Blunch, 2012). The most popular techniques within structural equation modelling when using AMOS is path analysis (Byrne, 2016). This technique was utilized in the current study to attain this aim. This technique relies on the path coefficient represented by the value of $\beta$ and the variations of this value between the casual relationships among the dependent variable, IT usage, and the dependent variable, TP, without the mediator, ITDR, and with the existence of it (Preacher, Zhang \& Zyphur, 2011). This means it is regarding calculating the impact of the intervening variable. Using indirect impact technique fits the SEM (Baron \& Kenny, 1986; Hayes, 2013, 2017). The results attained via AMOS's matrices are shown in Table 5.

Table 5 indirect and direct ipmacts

\begin{tabular}{|l|l|l|l|l|}
\hline Relationship & Direct impact & $p$-value & Indirect impact & $p$-value \\
\hline IT TP $\longrightarrow$ & 0.036 & 0.05 & 0.542 & 0.05 \\
\hline
\end{tabular}

Note: significant at $p \leq 0.05$

\section{Discussion}

The results of the main hypothesis shows that there is a relationship between the use of IT usage and task performance in JPUs. This confirms that the employee uses IT to completes their tasks and enhance their capabilities. Technology is a complementary and supportive mean for the employee's task performance, However, some departments still using traditional way of performance (e.g. paperwork to perform tasks) which allows wastage and loss in money and efforts that can be saved by using a computer and a program that can be developed by the IT Department. This confirms that IT has a significant impact on increasing the ability to perform the tasks among employees (Ahmed, Abu-Naser, El Talla, \& Al Shobaki, 2018; Eljhani \& Ameen, 2020; Khalifa, 2016; Othman, 2019; Choi, Lee, \& Yoo, 2010; Heim \& Peng, 2010; Mikalef \& Pateli, 2017; Sánchez-Rodríguez \& Martínez-Lorente, 2011) as they all indicate that IT usage has a positive effect on employee's task performance.

Furthermore, the results also display that there is a direct positive impact of the IT usage on the quality of performance, the speed of performance, the efficiency of performance, and the simplification of work in JPUs. Undoubtedly, the capabilities of employees and their experiences differ from one to another and this cou; $d$ be reflected in the quality of task performance, but IT has reduced this gap by improving the ability of employees to perform tasks, as IT facilitated the ability to complete work with high quality. contributed to the speed of performance by reducing the time required to complete tasks and accessing data by providing means of communication between employees, close distances, linking the various departments into one network and changing the organizational structure within the 
university. IT has contributed to reducing the time and effort that the employee spends, so that the employee uses many advanced equipment and devices at work to accomplish various professional tasks, such as using the computer, printer, the Internet, etc., which led to an increase in efficiency of performance (Attia, 2012; Eljhani \& Ameen, 2020; Jalagat \& Al-Habsi, 2017; Rezaei, et al., 2014; Wanjiru \& Abdalla, 2014).

Simirarly, the results show that there is a direct and positive impact of ITDR on TP, that is, IT department smoothing flow of work and remove obstacles to performing tasks. In the age of globalization, the benefits and consequences of IT in several settings have to be analyzed and understood, to take care of the need for automation. Additionally, IT Department supplies other departments with necessary requirements to be able to carry out their duties to the fullest. Moreover, the obtained result show that the IT department role has partially mediated the relationship between IT usage and task performance. The IT Department is responsible for organizing the administrative process and distributing tasks, which contributes to saving time and effort for both academic or administrative employess at the university by developing programs that contribute to improving the performance of employees and organizing their work and achieve university needs, just as the use of systems and information programs developed by IT department contributes to the process of improving productivity and raising quality, and also guarantees excellent efficiency in the job performance of university employees (El-Dalabieh, 2019).

\section{Theortical and Practical Implications}

The current study contributes to the administrative society and science in both levels. First, from a theoretical perspective, consistent with Attia (2012), Eljhani \& Ameen (2020); Jalagat \& Al-Habsi (2017), Rezaei et al. (2014) and Wanjiru \& Abdalla (2014), IT usage was found to have a direct positive impact on TP. It offers further information and indication about the effective impact of IT usage in enhancing TP. It is differ from previous researches, in that, comprised two or more sorts of performance such as organizational, product and service, and employees' performance within the same investigation or in different ones (Azadeh, Keramati \& Panahi, 2009; Barczak, Sultan \& Hultink, 2007). The propsed relations incorporated in the current study have not, up to date, been investigated in the Jordanian context, predominantly, in the higher education sector (Cui, Zhang, Zhang, \& Huang, 2008). On the one hand, the current study exposed the ambiguity that contexts the impact of IT usage within JPUs. On the other hand, the results explained, exclusively that ITDR operates as a mediator in the relationship between IT usage and TP within the same context.

Moreover, the current study has similarly practical implications for decision-makers in JPUs. Considerably, IT usage is a approach of leading practise in current era that has progressively dominated both sectors, private and public (Prasad, 2009). Consequently, the significance of this approach should be highlighted as well as the way that this approach facilitates activities among the organisations. Prior studies designated that IT usage is helpful tool in conducting and accomplishing of the job with saving time and efforts (Attia, 2012; Eljhani \& Ameen, 2020; Jalagat \& Al-Habsi, 2017; Rezaei, Rezaei, Zare, Akbarzadeh, \& Zare, 2014; Wanjiru \& Abdalla, 2014). Also, the current study creates additional support to the validity and reliability of the instruments and scales that have been utilized in accomplishing the study which measured IT, ITDR, and TP within a new context, Jordan. 


\section{Limitions and Directions for Future Researches}

As any research work, this study has number of limitations that could be directions for future researches. First, this is a cross-sectional study that depends on a set of data that gathered in a certain time from a certain sample in one context. Consequently, a comparison studies is likewise required in this field. Further, additional highlighting on longitudinal research have to to be considered. Whereas, longitudinal studies permit the researchers to observe in-depth the phenomenon (Bell \& Jones, 2015; Fraley \& Hudson, 2014; Huber, 1995; Ployhart \& Vandenberg, 2010). Second, the model that depicts the proposed relationships in this study developed by the researchers themselves based on an in-depth literature review. Future researches may take the advantage to use this model and verifying its dependability in other contexts. Third, this study has limited the investigation to one sort of performance that is task performance. Therefore, different sorts of performance such as organisational, technological, financial, process, nonfinancial, and administrative performance might be included for future researches. Fourth, IT department role has been investigated in this study as a mediator, future researches might incorporate different variables that can impact the relationship between IT usage and TP.

\section{References}

Abouelmagd, M. (2016, 3 19). The impact of information technology on organizational performance. An applied study on Oil \& Gas companies in Egypt. Unpuplished Doctoral Thesis . Cairo, Cairo, Egypt: Ain Shams University.

Agarwal, R., \& Sambamurthy, V. (2002). Principles and Models for Organizing the IT Function. MIS Quarterly Executive, 1(1), 1-16.

Ahmed, A., Abu-Naser, S. S., El Talla, S. A., \& Al Shobaki, M. J. (2018). The Impact of Information Technology Used on the Nature of Administrators Work at Al-Azhar University in Gaza. International Journal of Academic Information Systems Research (IJAISR), 2(6), 1-20.

Almarri, K., \& Gardiner, P. (2014). Application of resource-based view to project management research: supporters and opponents. Procedia-Social and Behavioral Sciences, 119(7), 437-445.

Ang, S., \& Slaughter, S. (2000). The missing of context information technology personnel: a review and future direction for research. In Zmud. R. (Ed.), Framing the Domains of IT Management: Projecting the Future through the Past (pp. 305-327). Cincinnati: Pinnaflex Educational Resources, Inc. .

Attia, A. (2012). The effect of using information technology on the job performance of workers in local government agencies: a field study at the University of Ouargla (Algeria). ElBahith Review, 233(1350), 1-18.

Azadeh, A., Keramati, A., \& Panahi, H. (2009). A hybrid GA-ant colony approach for exploring the relationship between IT and firm performance. International Journal of Business Information Systems, 4(5), 542-563.

Barczak, G., Sultan, F., \& Hultink, E. J. (2007). Determinants of IT usage and new product performance. Journal of product innovation management, 24(6), 600-613.

Baron,, R. M., \& Kenny, D. A. (1986). The moderator-mediator variable distinction in social psychological research: Conceptual, strategic, and statistical considerations. Journal of personality and social psychology, 51(6), 1173-1182.

Bell, A., \& Jones, K. (2015). Explaining fixed effects: Random effects modeling of time-series cross-sectional and panel data. Political Science Research and Methods, 3(1), 133-153. 
Benlian, A. (2015). IT feature use over time and its impact on individual task performance. Journal of the Association for Information Systems, 16(3), 144-173.

Berkley, B. J., \& Gupta, A. (1994). Improving service quality with information technology. International journal of information management, 14(2), 109-121.

Blunch, N. (2012). Introduction to structural equation modeling using IBM SPSS statistics and AMOS (2nd ed.). London: Sage.

Bromiley, P., \& Rau, D. (2016). Operations management and the resource based view: Another view. Journal of Operations Management, 41, 95-106.

Brown, S. L., \& Eisenhardt, K. M. (1997). The Art of Continuous Change: Linking Complexity Theory. and Time-Paced Evolution in Relentlessly Shifting Organizations, 42(1), 1-34.

Brynjolfsson, E., \& Hitt, L. M. (2000). Beyond computation: Information technology, organizational transformation and business performance. Journal of Economic perspectives, 14(4), 23-48.

Byrne, B. M. (2016). Structural Equation Modeling With AMOS Basic Concepts, Applications, and Programming (3rd ed.). New York: Routledge.

Choi, S. Y., Lee, H., \& Yoo, Y. (2010). The impact of information technology and transactive memory systems on knowledge sharing, application, and team performance: A field study. MIS quarterly, 34(4), 855-870.

Creswell, J. W., \& Creswell, J. D. (2017). Research design: Qualitative, quantitative, and mixed methods approaches. London, UK: Sage publications.

Cui, L., Zhang, C., Zhang, C., \& Huang, L. (2008). Exploring IT adoption process in Shanghai firms: An empirical study. Journal of Global Information Management (JGIM), 16(2), 1-17.

Eljhani, H. M., \& Ameen, A. (2020). The Role of Information Technology in Libyan Organizations. International Journal of Management and Human Science (IJMHS), 4(1), 30-36.

Faraj Allah, A. M. (2012, 12 11). The role of investment in information technology in developing institutional performance in Palestinian higher education institutions. Puplished Master Thesis. Gaza, Gaza, Gaza: Islamic University of Gaza.

Fraga-Lamas, P., Fernández-Caramés, T. M., \& Castedo, L. (2017). Towards the Internet of smart trains: A review on industrial loT-connected railways. Sensors, 17(6), 1457-1501.

Fraley, R. C., \& Hudson, N. W. (2014). Review of intensive longitudinal methods: an introduction to diary and experience sampling research. The Journal of Social Psychology, 154(1), 89-91.

Gordon, S. R., \& Tarafdar, M. (2010). The IT Audit That Boosts Innovation. Sloan Management Review, 51(4), 39-47.

Gupta, M., \& George, J. F. (2016). Toward the development of a big data analytics capability. Information \& Management, 53(8), 1049-1064.

Hair, J., Black, W., Babin, B., \& Anderson, R. (2010). Multivariate data analysis (7th ed.). Upper Saddle River, NJ, USA: Prentice-Hall, Inc.

Hampel, R., \& Pleines, C. (2013). Fostering student interaction and engagement in a virtual learning environment: An investigation into activity design and implementation. Calico Journal, 30(3), 342-370.

Hanson, M. (2001). Institutional theory and educational change. Educational administration quarterly, 37(5), 637-661.

Hart, S. L. (1995). A natural-resource-based view of the firm. Academy of management review, 20(4), 986-1014. 
Hayes, A. F. (2013). Introduction to mediation, moderation, and conditional process analysis: Methodology in the Social Sciences. New York, USA: The Guilford Press.

Hayes, A. F. (2017). Introduction to mediation, moderation, and conditional process analysis: A regression-based approach. New York: Guilford publications.

Heim, G. R., \& Peng, D. X. (2010). The impact of information technology use on plant structure, practices, and performance: an exploratory study. Journal of Operations Management, 28(2), 144-162.

Huber, G. P. (1995). Longitudinal field research methods: Studying processes of organizational change (Vol. 1). London, UK: Sage.

Jabbouri, N. I., Siron, R., Zahari, I., \& Khalid, M. (2016). Impact of information technology infrastructure on innovation performance: an empirical study on private universities in Iraq. Procedia Economics and Finance, 39, 861-869.

JALAGAT, J. D., \& AL-HABSI, N. (2017). Evaluating the Impacts of IT Usage on Organizational Performance. EUROPEAN ACADEMIC RESEARCH, V(9), 5111-5164.

Jasperson, J. S., Carter, P. E., \& Zmud, R. W. (2005). A comprehensive conceptualization of post-adoptive behaviors associated with information technology enabled work systems. MIS quarterly, 29(3), 525-557.

Kane, G. C., \& Alavi, M. (2007). Information technology and organizational learning: An investigation of exploration and exploitation processes. Organization Science, 18(5), 796-812.

Karimi, J., Karimi, T. M., \& Bhattacherjee, A. (2007). The role of information systems resources in ERP capability building and business process outcomes. Journal of Management Information Systems, 24(2), 221-260.

Kiesler, S., \& Sproull, L. (1982). Managerial Response to Changing Environments: Perspectives on Problem Sensing from Social Cognition. Administrative Science Quarterly, 27(4), 548-570.

Koenig, M. E. (2013). Information driven management concepts and themes: a toolkit for librarians (Vol. 86). Munchen, Germany: Walter de Gruyter.

Koopmans, L., Bernaards, C. M., Hildebrandt, V. H., Schaufeli, W. B., de Vet Henrica, C. W., \& van der Beek, A. J. (2001). Conceptual frameworks of individual work performance: A systematic review. Journal of occupational and environmental medicine, 53(8), 856866.

Koopmans, L., Bernaards, C., Hildebrandt, V., van Buuren, S., Van der Beek, A. J., \& de Vet, H. C. (2013). Development of an individual work performance questionnaire. International journal of productivity and performance management, 62(1), 6-28.

MacKinnon, D. P., Cheong, J., \& Pirlott, A. G. (2012). Statistical mediation analysis. In P. M. H. Cooper, APA handbooks in psychology ${ }^{\circledR}$. APA handbook of research methods in psychology, Vol. 2. Research designs: Quantitative, qualitative, neuropsychological, and biological (pp. 313-331). Washington, DC: American Psychological Association.

Marler, J. H., Liang, X., \& Dulebohn, J. H. (2006). Training and effective employee information technology use. Journal of Management, 32(5), 721-743.

Meyer, J. W., \& Rowan, B. (1977). Institutionalized organizations: Formal structure as myth and ceremony. American journal of sociology, 83(2), 340-363.

Mikalef, P., \& Pateli, A. (2017). Journal of Business Research. Journal of Business Research, 70, 1-16.

Motowildo, S. J., Borman, W. C., \& Schmit, M. J. (1997). A theory of individual differences in task and contextual performance. Human performance, 10(2), 71-83. 
O'Leary, D. E. (2000). Enterprise resource planning systems: systems, life cycle, electronic commerce, and risk. New York, USA: Cambridge university press.

Pawlowski, S. D., \& Robey, D. (2004). Bridging User Organizations: Knowledge Brokering and the Work of Information Technology Professionals. MIS Quarterly, 28(4), 645-672.

Ployhart, R. E., \& Vandenberg, R. J. (2010). Longitudinal research: The theory, design, and analysis of change. Journal of management, 36(1), 94-120.

Prasad, A. (2009). Understanding successful use of technology in organisations in developing countries: a structurational perspective. The Electronic Journal of Information Systems in Developing Countries, 37(1), 1-9.

Preacher, K. J., \& Hayes, A. F. (2004). SPSS and SAS procedures for estimating indirect effects in simple mediation models. Behavior research methods, instruments, \& computers, 36(4), 717-731.

Preacher, K. J., Zhang, Z., \& Zyphur, M. J. (2011). Alternative methods for assessing mediation in multilevel data: The advantages of multilevel SEM. Structural Equation Modeling, 18(2), 161-182.

Rezaei, M., Rezaei, M., Zare, M., Akbarzadeh, H., \& Zare, F. (2014). The effects of information technology (IT) on employee productivity in Shahr Bank (case study of Shiraz, Iran). Applied Mathematics in Engineering, Management and Technology, 10, 1208-1214.

Ross, J. W., Weill, P., \& Robertson, D. C. (2006). Enterprise Architecture as Strategy: Creating a Foundation for Business Execution. Boston: Harvard Business Press.

Sánchez-Rodríguez, C., \& Martínez-Lorente, A. R. (2011). Effect of IT and quality management on performance. Industrial Management \& Data Systems, 111(6), 830-848.

Scott, W. R. (2005). Institutional theory: Contributing to a theoretical research program. In Ken G. Smith and Michael A. Hitt, eds, Great Minds in Management: The Process of Theory Development (Vol. 37, pp. 460-484). Oxford, UK: Oxforod University Press.

Sobel, M. E. (1982). Asymptotic confidence intervals for indirect effects in structural equation models. Sociological methodology, 13, 290-312.

Swanson, E. B., \& Ramiller, N. C. (2004). Innovating mindfully with information technology. MIS Quarterly, 28(4), 553-583.

Tarafdar, M., \& Tanriverdi, H. (2018). Impact of the information technology unit on information technology-embedded product innovation. Journal of the Association for Information Systems, 19(8), 1-58.

Taylor, S., \& Todd, P. (1995). Assessing IT usage: The role of prior experience. MIS quarterly, 19(4), 561-570.

Terziovski, M. (2010). Innovation practice and its performance implications in small and medium enterprises (SMEs) in the manufacturing sector: a resource-based view. Strategic Management Journal, 31(8), 892-902.

Tina Dacin, M., Goodstein, J., \& Richard Scott, W. (2002). Institutional theory and institutional change: Introduction to the special research forum. Academy of management journal, 45(1), 45-56.

Ting, D. S., Carin, L., Dzau, V., \& Wong, T. Y. (2020). Digital technology and COVID-19. Nature medicine, 26(4), 459-461.

Turban, E., Leidner, D., McLean, E., Wetherbe, J., \& Cheung, C. (2006). Information technology for management: Transforming organizations in the digital economy. Richmond, USA: Wiley. 
Uwizeyemungu, S., \& Raymond, L. (2010). Linking the effects of ERP to organizational performance: Development and initial validation of an evaluation method. Information Systems Management, 27(1), 25-41.

Vera, D., \& Crossan, M. (2003). Organizational learning and knowledge management: Toward an integrative framework. In M. Easterby-Smith \& M. Lyles (Eds.), Handbook of organizational learning (pp. 122-141). Oxford,UK: Blackwell.

Wang, B., Liu, Y., \& Parker, S. (2020). How Does the Use of Information Communication Technology Affect Individuals? A Work Design Perspective. Academy of Management AnnalsVol, 14(2), 1-73.

Wanjiru, D. K., \& Abdalla, A. (2015). Effects of Information Communication Technology Adoption on Procurement Process in Kenya's Oil Industry: A Survey of Total Kenya Limited Mombasa County. International Journal of Management and Commerce Innovations, 2(2), 89-116.

Wernerfelt, B. (1984). A resource-based view of the firm. Strategic management journal, 5(2), 171-180.

Wu, F., Yeniyurt, S., Kim, D., \& Cavusgil, S. T. (2006). The impact of information technology on supply chain capabilities and firm performance: A resource-based view. Industrial Marketing Management, 35(4), 493-504. 